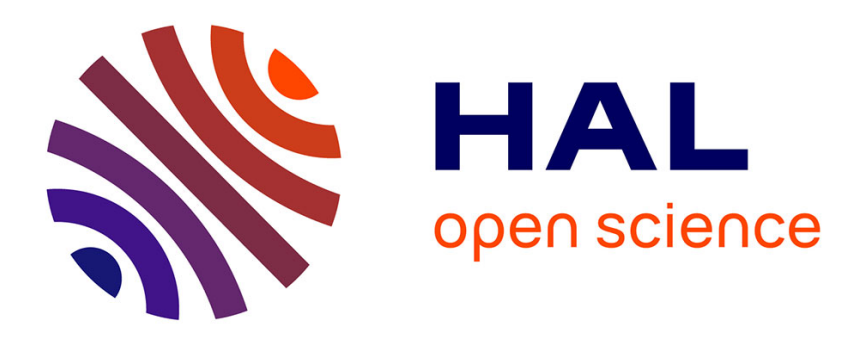

\title{
European Integration, Policy Autonomy and Partisan Politics
}

Jakob de Haan, Thomas Plümper

\section{To cite this version:}

Jakob de Haan, Thomas Plümper. European Integration, Policy Autonomy and Partisan Politics. European Union Politics, 2006, 7 (2), pp.163-166. 10.1177/1465116506063843 . hal-00571729

\section{HAL Id: hal-00571729 \\ https://hal.science/hal-00571729}

Submitted on 1 Mar 2011

HAL is a multi-disciplinary open access archive for the deposit and dissemination of scientific research documents, whether they are published or not. The documents may come from teaching and research institutions in France or abroad, or from public or private research centers.
L'archive ouverte pluridisciplinaire HAL, est destinée au dépôt et à la diffusion de documents scientifiques de niveau recherche, publiés ou non, émanant des établissements d'enseignement et de recherche français ou étrangers, des laboratoires publics ou privés. 
EUP

European Union Politics

DOI: $10.1177 / 1465116506063843$

Volume 7 (2): 163-166

Copyright@ 2006

SAGE Publications

London, Thousand Oaks CA,

New Delhi
European Integration, Policy Autonomy and Partisan

\section{Politics}

\author{
Jakob de Haan \\ University of Groningen, The Netherlands \\ Thomas Plümper \\ University of Essex, UK
}

European integration reduces the policy autonomy of the member states of the European Union (EU). For instance, the harmonization of regulation, the common monetary policy of the European Central Bank (ECB), and the rules of the Stability and Growth Pact (SGP) concerning national fiscal policy all lead to an erosion of national policy autonomy. Indeed, in the popular discourse on Europe, there is a widespread belief that nowadays most, if not all, policies come from 'Brussels' and that, therefore, national politics no longer matter.

Of course, this is not true for a variety of reasons. First, the EU has not harmonized all possible policy areas and has no intention to do so. Since much is left for the nation-state and subnational polities, politicians may still disagree with each other. Second, even in the policy domains in which the EU members have agreed to harmonize policies, these efforts often fall short of leading to full convergence, thereby leaving some room for policy divergence between countries. Political parties can use the remaining degrees of freedom to formulate diverging positions. Third, since politicians know that EU harmonization leads to an erosion of credible policy disagreement, they may at one point be reluctant to push ahead with EU harmonization simply to maintain leverage for political disagreement. In other words, democratic politics require disagreement and, since politicians are aware of this, they are unlikely fully to codify regulations and policies at the EU level even if full harmonization were an efficient and viable solution (which, of course, it is not). For all these reasons, European integration will not completely remove 
the member states' policy autonomy. Thus, political competition at the national level will remain intact and important.

The decision-making structure of the EU can be characterized as powersharing between national and supranational authorities. European integration is a process by which bargaining power is shifting from the national to the European institutions. This process has the tendency gradually to reduce policy autonomy, thereby limiting the room for political disagreement in national arenas. This special issue of European Union Politics brings together papers that analyse the EU's influence on policy autonomy and its consequences for partisan competition.

One interesting area from the perspective of this special issue is labour market policies; these policies aim to improve job seekers' prospects of finding employment and increase the productivity and earning potential of workers. They include spending on public employment, labour market training, and other policies intended to promote employment among the unemployed. What makes this area somewhat different from many others is the role of externalities; i.e. the effects of these policies spill across national boundaries, creating incentives for European governments to free ride off the efforts of their neighbours. In this issue, Franzese and Hays (pp. 167-189) provide empirical evidence that an increase in expenditures in one country indeed decreases equilibrium expenditures in its neighbours, so that current levels of spending may be too low. Franzese and Hays conclude that stronger enforcement procedures may be necessary if the EU is to achieve its labour market policy objectives.

Another interesting field is national fiscal policy. Owing to the SGP, the freedom to use fiscal policy for national political purposes has been restricted. However, this does not imply that European governments have no room for manoeuvre at all. Indeed, in their contribution to this special issue, Mink and de Haan (pp. 191-211) examine whether there is a political budget cycle in the countries in the euro area and find strong evidence that fiscal policymakers in the euro area have pursued expansionary policies before elections. This evidence is based on a multivariate model for 1999-2004, which is robust to the use of various election indicators. Interestingly, the authors find that in an election year - but not in the year prior to the election - the budget deficit increases. They also find a significant but small partisan effect on fiscal policy outcomes.

Not all EU member countries have adopted the euro, either because they do not meet the so-called convergence criteria outlined in the Maastricht Treaty (Sweden), or because they have an opt-out clause (the UK and Denmark). In the latter case, the countries concerned may decide not to join the currency union even if they meet the convergence criteria. Yet, the fact 
that these countries are outside the euro area does not imply that they have not been affected by the introduction of the euro. Plümper and Troeger argue in this issue (pp. 213-234) that the European common currency reduced the de facto monetary policy autonomy of the EU countries that did not introduce the euro. An empirical analysis of monetary policy in the UK, Denmark and Sweden shows that these countries' monetary policies follow more closely the ECB's policy than they had followed the Bundesbank's policy before 1994. In addition, Plümper and Troeger demonstrate a diminishing influence of the US dollar on monetary policy in the UK, Denmark and Sweden since the countries in the euro area harmonized monetary policies.

In sum, these papers provide ample evidence for policy spillovers, which in none of the three analysed cases completely abolish national policy autonomy. However, decisions at the national level are clearly affected by EU integration, even though the European level does not strictly harmonize the analysed policies.

What drives the extent to which the ambitions of political parties reflect the increased role of the EU? How does the growing role of the EU influence partisan competition at the domestic level? In a democratic system, political parties have different policy objectives, although there may be a tendency towards convergence to the position of the median voter. Dorussen and Nanou (pp. 235-256 in this issue) analyse whether there is more convergence of party policy platforms on those issues on which the EU has gained policy competence. Using manifesto data for the policy platforms of approximately 155 political parties in 15 EU member states (from 1951 to 2001), they find that European integration has increasingly constrained the range of policy platforms, in particular for parties that are in government and parties that are generally pro-EU. However, European integration does not appear to restrict the policy range of the potential minimum winning coalition.

Pennings (pp. 257-270 in this issue) compares the degree of Europeanization of national party manifestos, using a newly established database that comprises the digitized party manifestos of political parties. He finds that the degree to which parties acknowledge the increasing impact of the EU on policy-making depends on factors such as the policy sector concerned, how long a country has been a member of the EU, the general attitude of parties towards European integration, and the degree of internal consensus on European issues.

In comparison with national budgets, the EU budget is very limited, being just over 1\% of the EU's GDP. The second-largest item in the EU budget is the so-called Structural Funds, which aim to support regions with low per capita income. Structural Funds are the key mechanism of regional redistribution in the EU. In their contribution to the next issue of European Union 
Politics (Vol. 7, No. 3), Kemmerling and Bodenstein (2006) apply the traditional approach on partisan politics and national redistribution to the EU's Structural Funds. They use a new data set on both the distribution of funds across regions and the distribution of vote shares for different factions of the European Parliament. They find that the traditional left vs. right cleavage matters: the strength of left parties in a region is positively related to the size of the transfers the region receives. They also find a relationship between Eurosceptic parties and transfers, but this link is much weaker.

The articles in this volume lead to the conclusion that EU integration indeed often reduces policy autonomy at the domestic level even if the EU does not fully harmonize policies. With European integration influencing domestic political decisions and reducing de facto policy autonomy, parties increasingly adjust their manifestos to reflect more closely the growing role of the EU. Yet there are still plenty of issues for the Left and Right to disagree about.

\section{References}

Kemmerling, Achim and Thilo Bodenstein (2006) 'Partisan Politics in Regional Redistribution: Do Parties Affect the Distribution of EU Structural Funds across Regions?', European Union Politics 7(3), forthcoming.

\section{About the authors}

Jakob de Haan is Professor of Political Economy in the Faculty of Economics, University of Groningen, PO Box 800, 9700 AV Groningen, The Netherlands.

Fax: +31503633720

E-mail: jakob.de.haan@rug.nl

Thomas Plümper is a Reader in the Department of Government, University of Essex, Wivenhoe Park, Colchester CO4 3SQ, UK.

E-mail: tpluem@essex.ac.uk 